\title{
Parasitic rachipagus conjoined twin: case report
}

\author{
Nima Khavanin, MD, ${ }^{1}$ John R. Ruge, MD, ${ }^{2}$ Frank A. Vicari, MD, ${ }^{3}$ Eric J. Belin, MD, ${ }^{4}$ \\ Robert G. Kellogg, MD, ${ }^{2}$ and Jordan P. Steinberg, MD, PhD'1
}

\begin{abstract}
1Department of Plastic and Reconstructive Surgery, The Johns Hopkins University School of Medicine, Baltimore, Maryland; and Divisions of ${ }^{2}$ Pediatric Neurosurgery, ${ }^{3}$ Pediatric Plastic Surgery, and 4Pediatric Orthopedic Surgery, Advocate Children's Hospital, Park Ridge, Illinois
\end{abstract}

\begin{abstract}
A parasitic twin represents a rare developmental anomaly in which an asymmetrical, nonviable conjoined twin is attached to the host body at the time of birth. Rachipagus is among the rarest of conjoined twin subtypes and typically features a parasitic twin mass attached at the spine. Herein, the authors review the literature and describe the case of a 9-month-old girl presenting with a rachipagus parasitic twin consisting of a fully developed set of lower extremities originating from the midline upper back. After a complete workup to delineate parasite and autosite anatomy, the parasitic twin mass was successfully excised by a multidisciplinary team of surgeons, and the resulting defect was closed in a single stage.
\end{abstract}

https://thejns.org/doi/abs/10.3171/2018.3.PEDS1822

KEYWORDS heteropagus twin; conjoined twin; parasitic twin; rachipagus twin; diplomyelia; congenital

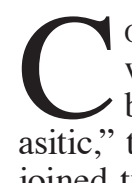

ONJOINED twinning is a rare developmental event with an approximate incidence of 1.47 per 100,000 births worldwide. ${ }^{11}$ The term heteropagus, or "parasitic," twinning is used to describe asymmetrically conjoined twins in which the tissues of a severely defective, generally nonviable, twin are dependent on the cardiovascular system of its intact counterpart, or "autosite." 19 Union occurs at homologous sites. These cases are further subdivided by the most prominent location of fusion. The recognized nomenclature includes 8 such sites: the chest (thoracopagus), umbilicus (omphalopagus), hip (ischiopagus), buttocks (pygopagus), spine (rachipagus), side (parapagus), cranium (craniopagus), and head (cephalopagus).$^{16}$ Herein, we review the existing literature and describe the surgical management of a patient presenting with a rachipagus parasitic twin, one of the rarest subtypes.

\section{Case Report}

Presentation and Examination

An otherwise healthy 9-month-old, full-term female infant was brought to Advocate Children's Hospital in Park Ridge, Illinois, for evaluation of an extra pair of limbs attached at the upper dorsal midline (Fig. 1A). Financial support for the patient's travel was provided by Children's
Medical Mission West, and medical services were donated by Advocate Children's Hospital and associated physicians. While personal issues did not allow the parents to accompany the child, limited birth and medical history information was available through local interpreters to Children's Medical Mission West. The patient was reportedly born via uncomplicated vaginal delivery in West Africa. She was noted to sit unsupported and appeared to have normal function of her native lower extremities, although she did not yet crawl. Her weight was $15 \mathrm{lbs} 8.5 \mathrm{oz}$ (1st percentile), and her height was 24 inches (8th percentile). Her head circumference was $44 \mathrm{~cm}$ (47th percentile). Physical examination demonstrated a well-developed infant with marked right posterior positional plagiocephaly and right head-turning preference. A pair of fully developed lower extremities originated from the midline cervicothoracic region, and the extremities exhibited spontaneous movement in the toes and apparent sensation.

Preoperative CT and MRI revealed a full bony pelvis and lower extremities originating from the craniocervical junction, a rudimentary scapula at the cervicothoracic junction, and two separate spinal canals with patent neural foramina indicative of cervicothoracic diplomyelia (Figs. 1B and 2). The posterior arches of the cervical vertebrae 

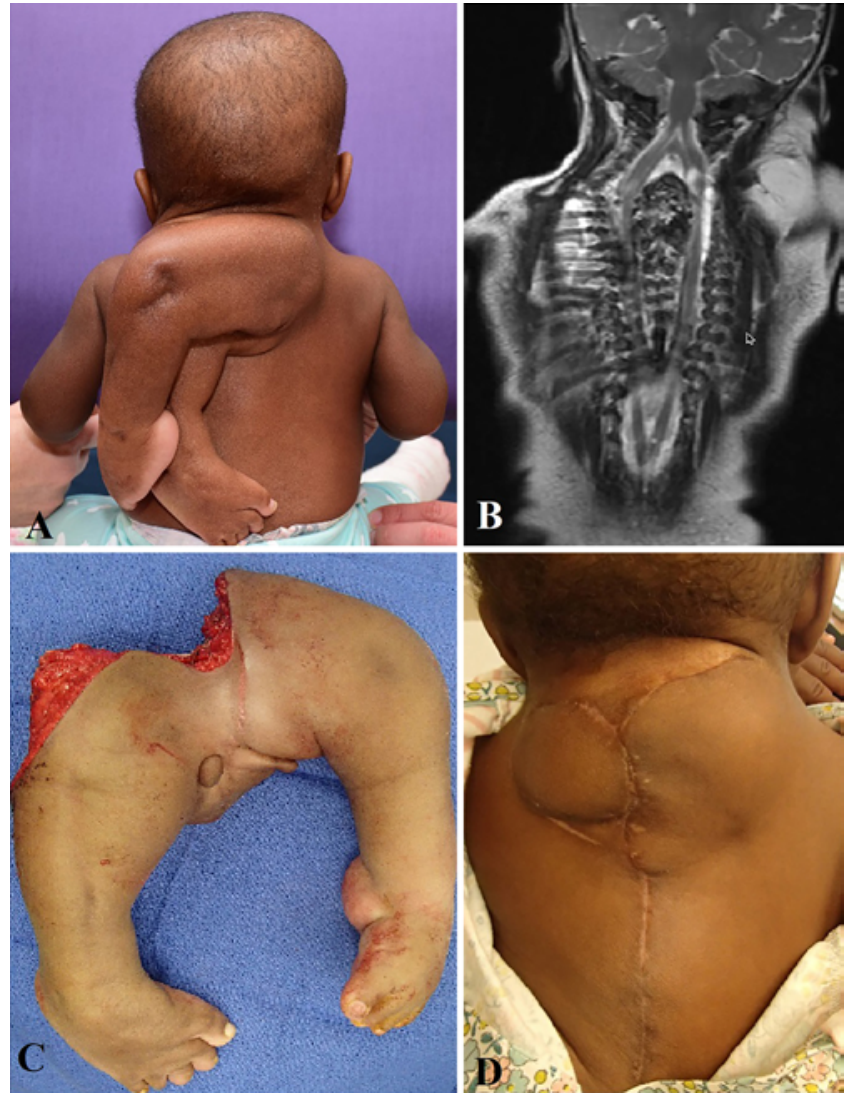

FIG. 1. A: Preoperative view of the 9-month-old girl with an extra pair of lower extremities attached at the midline of the dorsal cervicothoracic junction. B: Preoperative MR image revealing cervicothoracic diplomyelia in addition to a full pelvis and lower extremities and a rudimentary scapula. C: The parasitic mass was successfully excised en bloc; the duplicated spinal columns were left untouched. D: By the 6th postoperative week, the patient was noted to be healing well with no neurological compromise. Figure is available in color online only.

were absent, and symmetrical dorsal intradural lipomas were noted at the cervicothoracic junction, with sinuses extending into the fatty extradural soft tissues. An intact nuchal ligament separated the soft tissues of the parasite pelvis from the spinal canal. A right thoracic kidney was noted that excreted normally into the autosite bladder. A bladder-like structure in the parasitic twin pelvis did not fill with contrast on urogram. There were no other organ system anomalies. A distinct vascular pedicle supplied the parasitic twin, with the artery arising from the aortic arch and vein draining into the superior vena cava via paired azygos veins within the epidural space of the duplicated spinal canals bilaterally.

\section{Operation}

The parasitic twin mass was excised by a multidisciplinary team consisting of pediatric neurosurgery, pediatric orthopedic surgery, and pediatric plastic surgery; a virtual surgical planning system aided in the surgery. The single, flat bone plate serving as the point of articulation between autosite and parasite was transected with a piezoelectric saw, and the bony pelvis and lower extremities were sepa-

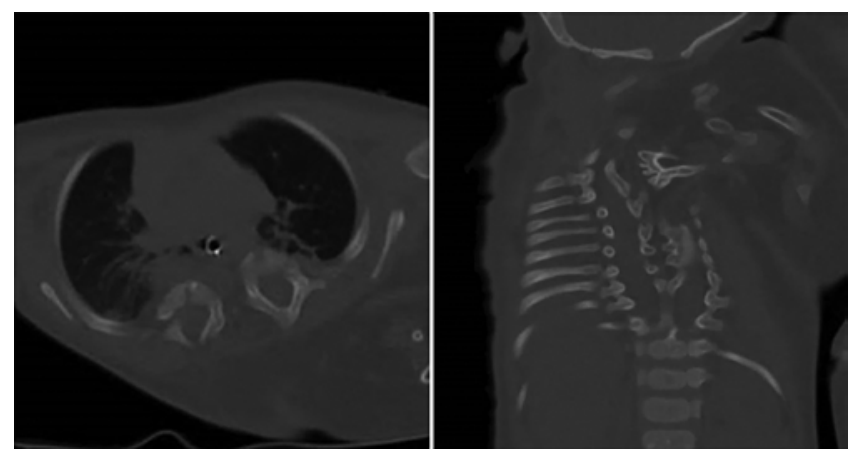

FIG. 2. Axial (left) and coronal (right) CT scans of the patient's thoracic spine demonstrating two separate spinal canals, each with separate neural foramen, supporting a diagnosis of diplomyelia.

rated off en bloc (Fig. 1C). Peripheral neurovascular bundles, seen to clearly supply the parasitic mass, were ligated as needed in a circumferential dissection approach. The spinal lipoma and diplomyelia were believed to be asymptomatic and therefore not addressed. Quadriceps musculature from the parasite was preserved and used to provide spare-parts flap coverage over the duplicated autosite spinal columns, which were left undisturbed.

\section{Postoperative Course}

Genetic analysis from the autosite and parasite revealed matching DNA profiles. By the 6th postoperative week, the patient was noted to be healing well, had no neurological compromise, and showed a rapid acceleration in her motor skill development (Fig. 1D). She was therefore given clearance to return to West Africa, where her local medical providers remained in communication with the surgical team. By 22 months of age, the patient was noted to be ambulating independently and meeting all developmental milestones.

\section{Discussion}

Even among conjoined twins, rachipagus is one of the rarest presentations. A 1995 review of 1200 cases of conjoined twins yielded only 21 that were fused at the spine, and of these, 20 were parasitic and 1 was complete with dorsal union of 2 fully developed infants. ${ }^{22}$ Since then, additional case reports and reviews of the literature have increased that total to over 30 cases, which run the gamut of parasitic skeletal and soft-tissue structures and autosite pathology (Table 1). ${ }^{1-3,12-15,17,20,23}$

As with our patient, the majority of reported cases are female and do not present with neurological deficits on examination..$^{10,12}$ Although any structure can theoretically be found in the rachipagus parasite, limbs are by far the most frequent. Cervical and thoracic parasites most commonly include segments of the upper limb and shoulder girdle, whereas those of the thoracolumbar and lumbar/ lumbosacral spine tend to include the lower limb and pelvic girdle. ${ }^{3,14}$ Reported soft-tissue findings include the full range of abdominal, pelvic, and retroperitoneal organs, external genitalia, glandular tissue, and even teratomatous/ lipomatous masses at their base. ${ }^{9,18,19,22}$ 
TABLE 1. Review of rachipagus twin cases reported within the literature

\begin{tabular}{|c|c|c|c|}
\hline Authors \& Year & Sex & Autosite Abnormality & Parasite Characteristic \\
\hline Albert et al., 2008 & $\mathrm{~F}$ & $\begin{array}{l}\text { Spinal dysraphism from L1 to S3, low-lying } \\
\text { conus medullaris w/ a myelocystocele, \& } \\
\text { diastematomyelia }\end{array}$ & $\begin{array}{l}\text { Soft-tissue mass w/ skin dimples resembling nipples \& bony mass } \\
\text { resembling a semi-segmented spine, ribs, scapula, \& clavicle }\end{array}$ \\
\hline Bayri et al., 2014 & M & $\begin{array}{l}\text { Lumbosacral meningocele, unfused vertebral } \\
\text { arches between L1 \& } 1 \text { 1 }\end{array}$ & Accessory lower extremity \& rudimentary hemipelvis \\
\hline Chadha et al., 2006 & $\mathrm{~F}$ & Sacral spina bifida & $\begin{array}{l}\text { Soft-tissue mass w/ rudimentary digits including a well-developed long } \\
\text { bone \& multiple small bones }\end{array}$ \\
\hline Krishra et al., 1989 & $\mathrm{~F}$ & Spina bifida & Fully formed lower extremity w/ rudimentary external genitalia \\
\hline \multirow[t]{2}{*}{ Navaei et al., 2015} & $\mathrm{~F}$ & None & Fully formed lower extremity \& hemipelvis \\
\hline & M & Neurogenic bladder & $\begin{array}{l}\text { Soft-tissue mass w/ rudimentary scrotum \& penis as well as bony struc- } \\
\text { tures resembling a scapula \& rib }\end{array}$ \\
\hline Ratan et al., 2004 & $\mathrm{~F}$ & Thoracolumbar spina bifida & Lipomatous mass w/ a rudimentary vertebral arch \& fused hindlimbs \\
\hline Rattan et al., 2016 & $\mathrm{~F}$ & None & $\begin{array}{l}\text { Ulcerated, multicystic mass } w / \text { rudimentary limb-like structures including } \\
\text { bone, cartilage, \& neural tissue on pathology }\end{array}$ \\
\hline Sahlu et al., 2016 & $\mathrm{~F}$ & Tethered spinal cord & $\begin{array}{l}\text { Lumbar mass w/ a well-formed lower extremity, rudimentary genitalia, \& } \\
\text { a sinus tract resembling an anal orifice }\end{array}$ \\
\hline \multirow[t]{2}{*}{ Sanoussi et al., 2010} & M & Meningocele, spinal lipoma & Fully developed lower limb \& rudimentary genitalia \\
\hline & M & Spina bifida & Dysmorphic upper limbs fused at the midline \\
\hline Solak et al., 2012 & $\mathrm{~F}$ & Spina bifida & Dysmorphic \& immobile upper limb w/ 4 small buds at the base \\
\hline Zhang et al., 2011 & $\mathrm{~F}$ & $\begin{array}{l}\text { Spina bifida, diplomyelia, scoliosis, tethered } \\
\text { cord, \& cardiac ventricular septal defect }\end{array}$ & $\begin{array}{l}\text { Soft-tissue mass including fully developed breast glandular tissue w/ an } \\
\text { external nipple-areola complex, uterine tube \& duct, bone, \& cartilage }\end{array}$ \\
\hline
\end{tabular}

Brief descriptions of an additional 20 cases are provided in a retrospective review of 1200 cases of conjoined twins by Spencer. ${ }^{22}$

Two theories have been proposed regarding the origin of this conjoined twinning: fusion and fission. Fission builds upon the etiology of monoamniotic twins, suggesting that a stimulus applied to the dorsal embryo slightly later in time may result in incomplete division and formation of conjoined twins. ${ }^{8}$ Conversely the fusion hypothesis argues that fusion of two distinct monoamniotic embryonic discs occurs at the site of an ectodermal defect; in the case of rachipagus twins, defects present at the neural folds during neurulation. ${ }^{21,22}$ In each case, subsequent intrauterine events lead to the demise of one twin, and the undeveloped parasitic tissue remains attached and dependent on the surviving twin. Both theories also explain the prevailing monozygosity of conjoined twins, ${ }^{8}$ as was confirmed by DNA analysis in our patient as well.

Unsurprisingly, the most common abnormalities in the autosite involve the CNS and vertebral column, usually close to the site of union. Varying degrees of fusion or fission explain many of the CNS findings, including the diplomyelia present in our patient, as well as the common finding of a neurovascular pedicle between the autosite and parasite. . $^{3,1422}$ Although less clear in their etiology, the prevalence of spinal dysraphism and masses (lipoma/teratoma) in this population is also ostensibly a consequence of this same event and subsequent anomalies in CNS development. ${ }^{3,22}$ The distinction between diastematomyelia, or sagittal splitting of the spinal cord, and diplomyelia, true duplication of the cord, can be difficult to make. However, the presence of two distinct spinal canals, each with separate neural foramen, in our patient (Fig. 2) favors the latter diagnosis of diplomyelia. Interestingly, other sig- nificant systemic abnormalities involving the autosite are rare (Table 1).,22 The thoracic kidney found in our patient appeared to function normally, although slightly delayed, despite its anomalous location.

Preoperative imaging helps delineate the extent of organ sharing and vascular connections between autosite and parasite. Echocardiography is a useful adjunct to evaluate for cardiac anomalies that may require intervention prior to separation. ${ }^{3,19}$ Otherwise, CT and MRI are the most commonly reported initial studies in heteropagus twins. Some authors report using Doppler ultrasound ${ }^{6,7}$ or MR angiography $y^{4,5}$ to identify the vascular pedicle to the parasite. Although not strictly necessary, we believe these minimally invasive techniques can greatly improve the safety of the procedure given the degree of anatomical variation that may be present. Any additional imaging should be tailored to specific findings that warrant further investigation. A CT urogram in our patient clarified the function and drainage of the right thoracic kidney into the autosite bladder rather than the cystic structure in the parasite pelvis.

With rare exception, surgical separation is undertaken perinatally on both cosmetic and psychosocial grounds but also because parasites may restrict the growth of autosites. ${ }^{19}$ The specific timing of repair varies from within the 1 st week of life to just under 1 year of age to allow the patient to grow. ${ }^{1}$ Unless the parasite is believed to be the source of respiratory or cardiovascular distress, the separation can be performed electively, with the timing determined by multidisciplinary conversation among anesthesiology, the surgical teams, the pediatrician, and the patient's caregivers. 


\section{References}

1. Albert G, Campos M, Menezes A, Vogel T, Weinstein S: Rachipagus parasite associated with myelocystocele and diastematomyelia. Pediatr Neurosurg 44:418-421, 2008

2. Bayri Y, Tanrıkulu B, Ekşi MS, Dağçınar A: Accessory lower limb associated with spina bifida: case report. Childs Nerv Syst 30:2123-2126, 2014

3. Chadha R, Lal P, Singh D, Sharma A, Choudhury SR: Lumbosacral parasitic rachipagus twin. J Pediatr Surg 41:e45e48, 2006

4. Cury EK, Schraibman V: Epigastric heteropagus twinning. J Pediatr Surg 36:E11, 2001

5. De Ugarte DA, Boechat MI, Shaw WW, Laks H, Williams $\mathrm{H}$, Atkinson JB: Parasitic omphalopagus complicated by omphalocele and congenital heart disease. J Pediatr Surg 37:1357-1358, 2002

6. Hager J, Sanal M, Trawöger R, Gassner I, Oswald E, Rudisch A, et al: Conjoined epigastric heteropagus twins: excision of a parasitic twin from the anterior abdominal wall of her sibling. Eur J Pediatr Surg 17:66-71, 2007

7. Kapur VK, Kulkarni MS, Shenoy MU: Asymmetric conjoined twins. Pediatr Surg Int 12:308-309, 1997

8. Kaufman MH: The embryology of conjoined twins. Childs Nerv Syst 20:508-525, 2004

9. Krishra A, Chandna S, Mishra NK, Gupta AK, Upadhyaya P: Accessory limb associated with spinal bifida. J Pediatr Surg 24:604-606, 1989

10. Martínez-Frías ML, Bermejo E, Mendioroz J, RodríguezPinilla E, Blanco M, Egüés J, et al: Epidemiological and clinical analysis of a consecutive series of conjoined twins in Spain. J Pediatr Surg 44:811-820, 2009

11. Mutchinick OM, Luna-Muñoz L, Amar E, Bakker MK, Clementi M, Cocchi G, et al: Conjoined twins: a worldwide collaborative epidemiological study of the International Clearinghouse for Birth Defects Surveillance and Research. Am J Med Genet C Semin Med Genet 157C:274-287, 2011

12. Navaei AA, Habibi Z, Moradi E, Nejat F: Parasitic rachipagus twins; report of two cases. Childs Nerv Syst 31:10011003, 2015

13. Pandey A, Singh SP, Pandey J, Gupta V, Verma R: Lumbosacral parasitic twin associated with lipomeningomyelocele: a rare occurrence. Pediatr Neurosurg 49:110-112, 2013

14. Ratan SK, Rattan KN, Magu S, Rohilla S, Purwar P, Mathur SK: Thoracolumbar rachipagus parasite. Pediatr Surg Int 20:298-300, 2004

15. Rattan KN, Singh J, Dalal P, Sonika P, Rattan A: Sacral rachipagus parasite: a case report. J Neonatal Surg 5:16, 2016

16. Rode H, Fieggen AG, Brown RA, Cywes S, Davies MR, Hewitson JP, et al: Four decades of conjoined twins at Red Cross Children's Hospital-lessons learned. S Afr Med J 96:931-940, 2006

17. Sahlu A, Mesfin B, Tirsit A, Debebe T, Wester K: Parasitic twin - a supernumerary limb associated with spinal malformations. A case report. Acta Neurochir (Wien) 158:611614, 2016

18. Sanoussi S, Rachid S, Sani CM, Mahamane B, Addo G: Rachipagus: a report of two cases - thoracic and lumbar. $\mathbf{J}$ Surg Tech Case Rep 2:27-29, 2010

19. Sharma G, Mobin SS, Lypka M, Urata M: Heteropagus (parasitic) twins: a review. J Pediatr Surg 45:2454-2463, 2010

20. Solak A, Ergün S, Polat I, Sahin N, Genç B: A rare form of heteropagus twinning: three-armed infant with spinal dysraphism. Case Rep Pediatr 2012:831649, 2012

21. Spencer R: Parasitic conjoined twins: external, internal (fetuses in fetu and teratomas), and detached (acardiacs). Clin Anat 14:428-444, 2001

22. Spencer R: Rachipagus conjoined twins: they really do occur! Teratology 52:346-356, 1995

23. Zhang J, Duan H, Zhang Y, Yi Z, Bao S: Parasitic rachipagus conjoined twins with spina bifida, diplomyelia, scoliosis, tethered cord syndrome, and ventricular septal defect-case report. Neurol Med Chir (Tokyo) 51:736-739, 2011

\section{Disclosures}

The authors report no conflict of interest concerning the materials or methods used in this study or the findings specified in this paper.

\section{Author Contributions}

Conception and design: all authors. Acquisition of data: Steinberg. Analysis and interpretation of data: Khavanin. Drafting the article: Khavanin. Critically revising the article: Steinberg, Ruge, Vicari, Belin, Kellogg. Reviewed submitted version of manuscript: all authors. Study supervision: Steinberg.

\section{Correspondence}

Jordan P. Steinberg: Johns Hopkins Children's Center, Baltimore, MD.jsteinb1@jhmi.edu. 